\title{
nature
}

\section{Collisions between science and media}

Premature release of scientific results to the public is against the interests of scientists, journalists and the public. The use of embargoed press releases is beneficial, and helps the quality of coverage of science in the media.

THEY did it with 'cold fusion' and they did it with 'life on Mars': in both cases, the mass media jumped the gun on scientific journals. And did it matter? Yes, because in both cases, good media coverage required analysis of what was being claimed, necessitating informed comments from other scientists. Furthermore, in both cases there was good cause for scepticism, even beyond the general principle that grand claims require exceptionally resilient evidence. In cold fusion, the predictions of quantum mechanics were apparently being contradicted. With Martian meteoritic hydrocarbons, the parallels with past discounted evidence of early life on Earth are obvious: the context of the evidence - ancient rocks subject to diverse thermal and chemical influences - can all too easily give rise to misleadingly suggestive signatures. But, in both cases, the lack of the relevant published material made prompt informed comment by outsiders difficult.

The benefits of peer review by journals as a means of giving journalists some confidence in new work are self-evident. Premature release to the media thus denies them that confidence as well as the ability to obtain informed reactions. But conflicting pressures sometimes override the interests embodied in the formal publication process. Scientists wishing to attract attention to themselves in order to influence funding agencies, and agencies wishing to influence governments through public pressure, may on occasion ride roughshod over the proprieties of scientific publication to achieve their ends. And in another science-and-media saga, that of bovine spongiform encephalopathy (BSE), governments have not hesitated to release information prematurely when it suited them. But such actions can backfire when apparently strong conclusions tumble before close scrutiny in the peer-review process.

Such stories are of international interest and carry significant news value: interested journalists are correspondingly numerous and determined. In the case of BSE, for example, some scientists have had virtually to disconnect themselves from the press to pursue their research effectively. All the more reason, therefore, for them, their institutions and journals to release information in a controlled way. That provides equal access to the press and, if the news is released a day or two ahead of publication, journalists can give their coverage the depth that it deserves - both they and the scientists benefit from the quality that is thus attainable.

The quoted examples are extreme, but their moral applies to less sensational science as well: a press release with an embargo a deadline before which nothing may be published - usually serves the interests of all involved. And, of course, it allows journals, too, to enhance their public profile.

For all those reasons, and like several other journals, Nature has refused to publish papers prematurely released to the press, and puts out its weekly release of summarized content to journalists, embargoed until the evening before the Thursday of publication. And the embargoes are taken seriously - those who break them have been removed from the circulation list.

Hindering communication between scientists is another matter, which is why different guidelines apply to work that has been discussed at a scientific conference and picked up by the media in the process. Conferences, of course, do not constitute prior publication - their contents are not immediately available to the wider community and the peer-review process of conferences is at best less thorough than for journals. (A substantial fraction of papers presented at conferences never appear in journals.)

Nature's guidelines for potential authors at such occasions are clear-cut in principle: talk to other researchers as much as you wish, but do not encourage or risk premature publication by discussion with the press, beyond your formal presentation. That advice may jar with those (including most researchers and all journalists) who see the freedom of information as a good thing. But it embodies a longer-term view: that publication in a peer-reviewed journal is the appropriate culmination of any piece of original research, and an essential prerequisite for public discussion.

\section{Don't ban sceptics}

Climatological lobbyists have given scepticism a bad name, and more credible criticism is at risk of suppression.

DURING a series of lively hearings last autumn before a subcommittee of the US House of Representatives, members of the Republican majority sought to find hard evidence that the peerreview process for environmental sciences is being corrupted by institutional bias. Allegations were made to the effect that scientists who held views at variance with those underpinning the policies of the Clinton administration were being unfairly treated. It was said that unnamed government officials had flatly stated that research with certain likely outcomes would not be funded and in later correspondence - that this journal had treated certain submissions unfairly.

But names were not named and the allegations appear to have fizzled out. Dana Rohrabacher, chair of the energy and environment subcommittee of the House Science Committee, who instigated the hearings, had every political incentive to follow up the accusations, but was unable to do so.

To that extent, George Brown (Democrat, California), the senior minority member on the Science Committee, is right to say that the hearings utterly failed to substantiate claims that biased peer review is corrupting the environmental sciences (see page 749). Brown is worried that the hearings, which called as witnesses established 'sceptics' about ozone depletion, global warming and dioxins, lent them too much credibility. He contends that by calling the 'sceptics' as witnesses next to scientists holding mainstream views, the hearings create a perception that no reliable process exists to resolve scientific differences of opinion. He fears that peer review will thus be discredited, and policy-making undermined.

It is odd for a liberal such as Brown to argue against the presentation of diverse views. The Science Committee lacks real power, but still serves as a valuable forum for science issues in the Congress. The voices of the sceptics may grow tiresome, but the mainstream is in trouble if it cannot win a public debate with them. If Brown resumes the chairmanship of the Science Committee, as he may do after next week's elections, he should make sure that the committee continues to hear from credible witnesses who are prepared to dispute the prevailing wisdom on environmental issues: there are plenty of them around. 